\title{
OVERVIEW OF THEORIES, MODELS AND POLITICAL DISCOURSE ON EDUCATION, DEMOCRACY AND FREEDOM
}

\author{
Albana Çekrezi \\ PhD. Candidate, Epoka University, ALBANIA, acekrezi17@epoka.edu.al
}

\begin{abstract}
The controversial link between education and politics has caught the attention of many classical, early modern and contemporary philosophers together with scholars, political scientists, and educational theorists. In contemporary debates, the link education-politics has narrowed to education-democracy and has aimed to target specific values. The following review offers a theoretical and philosophical overview of education and politics, continues with education and democracy, and centralizes on the democratic value of freedom. The presented theories and models orient education towards politics, democracy, and the democratic value of freedom. Initially, the connection between education and politics is discussed from a philosophical perspective. Theoretically, education effect theory, and models on education and democratic values are elaborated. The review is furthered in more specific details with the examination of the connection between freedom and education. This relation is presented as grounded on four perspectives: the progressivist, critical theory, liberal and deliberative view. Apart from classical scholars like Rousseau, Mill, Dewey, Habermas, contemporary authors like Nussbaum, Freire, Greene, Gutmann, new scholars are added to the debate. Overall, this review aims to map and position the theoretical, philosophical and political perspectives found on education and politics with a focus on the democratic value of freedom. The review indicates that theoretically the link is still controversial and in need of further exploration as concerns implementation.
\end{abstract}

Keywords: education, politics, democracy, freedom

\section{INTRODUCTION}

Over the years, the quality of the people that govern us has been at the center of philosophical and political debates. Various assumptions, theories, or models have been produced to explain the possible impact that education has on citizenry. The review starts with Greek philosophers and their aspirations on the effects of education. Socrates, Plato, and Aristotle's perspective of education aims the formation of citizens refined in character and knowledge. Early modern philosophers like Kant or Rawls believed societies should be educated, whereas Mill opposed ordinary people being involved in politics. On the other hand, modern scholars consider education a necessary condition or precondition for democracy. It stimulates thoughts, improves character, impacts growth, and overall, it affects political culture. As concerns theories, the theory of the education effect is presented with two lines: the correlated effects and the direct effects model. Models of education and democratic values emphasize the psychodynamic model, the cognitive model, and the socialization model. Lastly, the review channelizes over education and the democratic value of freedom. It discusses the progressivist, critical theory, liberal and deliberative view. Each of these perspectives is a 
detailed insight of how freedom can be stimulated through education.

\section{PHILOSOPHICAL DISCUSSION OVER DEMOCRATIC VALUES AND EDUCATION}

Many authors, starting from the classical, early modern, and coming to contemporary philosophers, scholars, political scientists, and educational theorists have argued on what impact education has over politics. Initially, many Greek philosophers have deliberated over this connection. To Socrates, education is necessary for the preparation of future citizens. He believed that the youth need to be guided and he defended a case-focused or individualistic education for democracy (Pangle, 1985). Other thinkers have stressed the fact that education has the potential to change or refine the character of the youth, processes which would impact politics. Plato and Aristotle set the roots of research on the influence of education on the youth. Plato's idealistic thoughts favored education for character and citizenship (Lodge, 2000); education that forms elites who will govern the state (Moore, 2010), and education that saves the youth from being blind to a world of faults (Murphy, 2015). Aristotle on the other hand believed that the final result of education should be the formation of good citizens and societies.

Other early modern philosophers have made their contribution to the matter. For Kant education should aim to make individuals moral (Forster, 2005); (Locke, 1692, 2021). Kant's understanding of education aims at the formation of a class of thinkers (Sorina \& Griftsova, 2017). Whereas J.S. Mill supported educational elitism, he was suspicious of the political ability of the electorate and therefore advised that the most judicious and knowledgeable citizens should have more votes than the working class (Held, 2006). For Rawls society should be rational and only those educated citizens who share a culture of norms and values should be in charge of institutions (Brooke \& Frazer, 2010).

In contemporary debates, the link education-politics has narrowed to education-democracy. Democracy, as randomly happens, should not be approached only from the elections' standpoint but nurtured as well (Carr \& Lund, 2011). And as a result, many present-day authors from the research community have elaborated on the potential and functions of education over democracy. They agree in theory that education positively affects democracy and explain the reasons for such an effect. Primarily, education is seen as a necessary criterion for democracy (Lipset, 1959). "If we cannot say that a "high" level of education is a sufficient condition for democracy, the available evidence does suggest that it comes close to being a necessary condition in the modern world" (Lipset, 1959, p. 80). As part of the socio-economic elements, it prepares favorable grounds for democracy (Fukuyama, 1992). Some researchers are of the idea that in a democratic environment, education, has an institutionalized effect (Meyer J. W., 1977); (Murtin \& Wacziarg, 2014); (Fortunato \& Panizza, 2015) and affects growth (Barro, 1999); (Baum \& Lake, 2003); (Glaeser, La Porta, Lopez-De-Silanes, \& Shleifer, 2004); (Chen, 2008); (Bittencourt, 2014).

When the level of educational attainment increases, so does the level of democracy (Alemán \& Kim, 2015). Additionally, citizenship education influences opinions and competencies related to citizenship (Keating, Benton, \& Kerr, 2012), and support for liberalism as well as right-wing ideology increase with extra years of education (Meyer A., 2016). This is possible because education impacts conceptualization on democracy. It stimulates ideas and understanding of democracy. Political thought is dependent on education (Jacoby, 1988). Additionally, political trust was influenced by education through the mediation of democratic values (Kołczyńska, 2020). Schools are among the main factors, next to family and the media that influence the way individuals conceptualize politics and democracy (Print, 2007). Schools (school context) that are organized democratically can help better promote a democratic culture (Harber, 1997). For this reason, factors related to the social and economic context of schools are to be evaluated and not underestimated (Buchmann \& Hannum, 2001). In a few words, education perpetuates the system (Dewey, 1916) and this has been supported by various studies across many counties (Karış \& Tandoğan, 2019); (Apergis, 2017); (Türedi \& Terzi, 2017).

\section{THEORETICAL MODELS}

As concerns the theoretical models that explain how education impacts politics, democracy, or democratic values specifically, below are presented two main models. The first one sets in general lines the rationale behind this connection through two models. The direct model explains the direct effect of education on politics. The second model, the relative one puts forward the fact that education, primarily, impacts elements like social status, and then, political outcome. This section covers also a more detailed model of democratic values. There are three strategies hypothesized to enable such effect: The psychodynamic model, The cognitive model, and The Socializing model. 


\subsection{The Education Effect}

As regards theoretical models, in broad lines, two main models expose the connection between education and politics: the correlated effects and the direct effects model which is represented by two essential lines: the direct model and the relative effect model (Emler \& Frazer, 1999). According to the correlated effects model, education, and politics (and their connected variables) are outcomes of third variables like cognitive abilities (verbal ability, reasoning) character traits, and socio-economic status of the individual. In this model, education is simply an outcome without effects on politics. Meanwhile, according to the direct effect model, education affects politics straightly because education (values and knowledge) influences political attitudes and knowledge directly. In the relative effects model, education affects primarily the social position like opportunities and network and then politics with the related engagement and attitudes. Thus, education indirectly influences politics. To generalize, the effect that education (more specifically formal education) has on politics can be in the form of the direct and indirect effect. More clearly these models are represented below:

\section{Direct effect model}

Education

Political outcome

Knowledge (political attitude)

\section{Relative effects model}

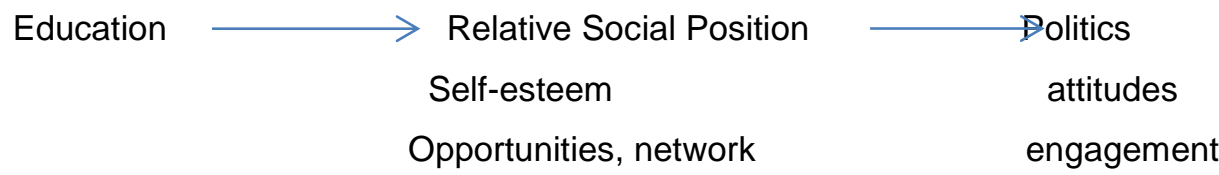

\subsection{Models on Education and Democratic Values}

Apart from the general theoretical explanation given above, a more elaborate version of the impact of education on democratic values has been theoretically proposed by Stubager (2008). Specifically, Stubager has suggested three detailed models that serve to explain the ways through which education affects values. These models explain the direct effect of education on democratic values through the psychodynamic model, the cognitive model, and the socialization model.

Formal education Direct effect The psychodynamic model (control your own life)

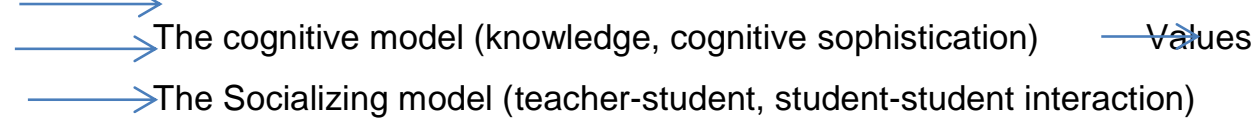

Firstly, the psychodynamic model considers education as influencing values through psychological characteristics. In this case, education improves one's security feelings. This means that individuals with higher levels of education feel less threatened by changes, and can control their life. As a result, they tend to be more tolerant. According to the psychodynamic model, educated citizens tend to have less discriminatory attitudes towards outsiders because normally they feel secure with themselves and as a result less threatened by others. On the other hand, the cognitive model is focused on the cognitive development of individuals. Education serves to improve knowledge and sophisticates it. More knowledge brings more tolerance for other cultures, but also a better understanding of the problems and issues that surround us. The final model, the socialization model consists of the idea that certain socializing agents and experiences serve to instill values in students. The teaching process, the teacher-student, and student-student interaction serve to impact the formation of values in students. Even though, the model received criticism because it does not explain how behaviors are learned; it views students as passive and not active individuals (Bowles \& Gintis, 2002).

\section{THEORETICAL DISCOURSE ON EDUCATION AND FREEDOM}

The upcoming section screens in a thorough manner the link between education and freedom, one of the most important democratic values. It introduces both philosophical and political perspectives. It can be noted that many views on the topic are grouped under the umbrella of the progressivist-liberal, critical theory, and deliberative standpoint.

\subsection{The Progressivist-Liberal View}

To begin with, various progressivists indicate that education is an example of domination and oppression 
rather than freedom. Rousseau is considered as one of the main philosophers who wrote on the education of the child and his freedom pointing to the idea that schools are institutions that limit freedom. Rousseau in his famous book "Emile or on Education" declares that "All his life long man is imprisoned by our institutions" (1762, p. 9). Based on this understanding, schools are important institutions and they shape the lives of children, but at the same time, in Rousseau's viewpoint, they invade the liberty of a child. It is the society and community that endanger man's liberty. However, he considers that education can help individuals achieve freedom through self-control.

In addition to this, J.S. Mill discusses freedom in education in his famous book "On Liberty" (1859). First of all, he defends the liberty of ideas, discussion, writing, and the press. He is a supporter of the expression of opinions and ideas, even if they are false. As concerns education, Mill advises the discussion and debate of topics in politics, religion, morality, and similar social subjects. Furthermore, he criticizes those teachers and students who remain comfortable in their positions of teaching and learning without questioning them. The "educated men" he claims, "... have never thrown themselves into the mental positions of those who think differently from them" (1859, pp. 67-68). This is to say that individuals do not take into consideration different perspectives or points of view. For this reason, Mill suggests that the educated should think beyond what they have been taught in schools by teachers and books. This is a certain critical judgment over what students are made to learn. A way to achieve this is through free discussion and free speech. Moreover, Mill warns on the dangers that may come from state education as regards freedom.

"A general State education is a mere contrivance for molding people to be exactly like one another: and as the mould in which it casts them is that which pleases the predominant_power in the government, whether this be a monarch, a priesthood, an aristocracy, or the majority of the existing generation in proportion as it is efficient and successful, it establishes a despotism over the mind, leading by natural tendency to one over the body." (Mill, On Liberty, 1859, p. 190).

State education can turn to be a device that will make students lose their distinctiveness by manufacturing the same type of citizenry which pleases the dominant authority. This would result in a lack of freedom, subordination, and obedience. Thus, mass education can result in despotism (West, 1965) and indirect censorship of liberty. This kind of education damages individual freedom and invades multiplicity of talents, character, etc. Education can serve to suppress the mind making it easier for the body to submit. In this understanding, Mill believes that education should have freedom from the state because the wisdom of the individual can surpass that of the people representing the state.

J. Dewey, a philosopher, and thinker of the $20^{\text {th }}$ century is another representative of this theoretical approach best characterized as a child-oriented philosophy. He critiques state education for its hierarchy, for its detachment from reality, and considers schools as a community in itself and part of a larger society (Darling \& Nordenbo, 2003). Education is not only crucial for politics, but it is a prerequisite for democracy too (Dewey, 1916). Experience, individuality, and practiced-based education are central to this philosophy (Radu, 2011). John Dewey remarkably wrote over the value of freedom in schools in his book "Democracy and Education" (Dewey, 1916). In the chapter entitled "The Individual and the World", he discusses freedom from two perspectives: personal freedom and social control. The first one is internal and the second one is external. For him, the core of freedom is the necessity of conditions that will help the individual contribute to the community. Dewey understands freedom in education more from a personal point of view. Freedom needs to direct individuals towards exploration. Dewey considers freedom in education as "the part played by thinking-which is personal-in learning: -it means intellectual initiative, independence in observation, judicious invention, foresight of consequences, and ingenuity of adaptation to them" (1916, p. 310). So, in some sense, he is an advocate of intellectual freedom. His conceptualization of freedom is also some kind of achievement in independent reasoning and argumentation. Dewey does not deny the importance of associations with others. Group work does not limit one`s freedom. Instead, freedom should serve to expand and refine knowledge, stimulate imagination, not solely reproduce, and memorize. Reproduction and memorization lead only to oppression and obedience to authority.

Adler, in general, considers compulsory education as a way to prepare youngsters as future citizens for citizenship and to be able to take the required responsibilities (Adler M., 1982). In education, he sees two forms of freedom: the laissez-faire that centralizes on students' spontaneity and interest, and the one that disciplines youngsters towards maturity (Adler M. J., 1958, p. 382). Adler considers freedom of choice as an opportunity where individuals somehow declare their interests and talents (Adler, 1983).

The current liberal debate is oriented towards democratic education and has extended beyond freedom, a dominant value in liberalism (Ten, 1969). Nussbaum's (2010) democratic education distinguishes between education that serves economic purpose and the one that is focused on humanities. This form of democratic 
education is based on five main pillars: capacity building, cooperation with the needy, consideration of others, familiarity with other cultures, and critical thinking. Alexander's (2007) liberal theory of education is based on a coexistence that is funded in self-realization, exposure to reality as against independence. On the other side, Pennington (2014) puts and questions parental freedom of choice in between discussions of the role of state and democratic education. For others, democratic education aims at knowledge and humanist goals, rather than specific subjects (Duarte, 2016). Biesta (2007) sees democratic education concerning the individual. This education considers the individual from three aspects: the individualistic, the social, and the political. The first two consider education as one of the sources which produce the citizen; the third one is more action-focused and requires individuals to experience.

\subsection{The Critical View}

On the other hand, critical theory, a school of thought linked to the Frankfurt School with representatives such as Habermas and Fromm, opposes forms of external oppression done to the individual and the society (Peca, 2000). Its bases are on the critique and questioning of the reality, of existing relations and status-quo through the acquisition of knowledge and truth. Habermas is one of the main representatives of critical theory (Keat, 1980). He viewed language as a tool of compromise and cooperation through an informed debate on important issues of education (Terry, 1997). He highlighted the colonizing practice of the system pointing to language as a solution that can be used to stop it. Habermas, a defender of liberal values, defends their construction through a critical society (Wain, 2004) to which education is the key. For him, democracy rests on communication and cooperation. In recent years, Miguel Martin-Sanchez and Cruz Flores-Rodriguez published an article entitled "Freedom and Obedience in Western Education" (2018) in which they criticize the education of the $21^{\text {st }}$ century in Western countries. According to them, this kind of education is leading students towards obedience. These schools limit critical thinking and autonomy. As a result, students are led to unconscious subordination through the acceptance of norms and the reproduction of the same ideas. In this perspective, freedom is that from obedience, which is also the negative type of freedom. Cognitive independence as a positive form of freedom is missing.

Critical pedagogy itself is sourced from critical theory. With critical pedagogy, critique is imported in the educational landscape, an area yet in need of exploration (Blake \& Masschelein, 2003). The Brazilian leading philosopher and educator Paulo Freire is unique in how he has voiced issues of oppression in education. In his celebrated book "Pedagogy of the Oppressed" (1970), he addressed the relation of education with freedom and oppression. Coming from an experience in Brazilian schools, Freire introduced the notion of oppression in education and the need for liberation. He is against any form of imposition but calls for dialogue (Durakoglu, Bicer, \& Zabun, 2013). Firstly, Paulo Freire refers to an approach found vastly in education. He termed it as "the banking concept" and considers students as passive recipients to being filled like empty vessels. This method dominates thought, stops critical thinking, and inhibits creativity. So, this banking approach in education damages freedom and leads to oppression and obedience. It controls their freedom of thought, expression, and action. He stresses that the relation between teacher-students is that of the oppressor and the oppressed. The result is the development of a culture of silence and the oppressed has no longer the ability to freely criticize the dominant culture. To Freire, politics and education are interrelated and education serves a certain political agenda. Education can offer freedom only when the students are considered as connected to the world, not isolated and not dehumanized. When the authority in schools is in favor of freedom, then students are thought of as conscious beings, not simply recipients. Freire's liberation is a process that makes people reflect on how to transform the world.

Similar ideas are supported by Fromm (2001) in "The Fear of Freedom". The scholar warns that education can damage genuineness and naturalness. Through the use of methods and other mechanisms, education shapes individuals so that they fit into society. In this way, it serves the purpose of the powerful by killing creativity and thinking. Instead, Glass (2004) in his article "Moral and Political Clarity and Education as a Practice of Freedom" suggests that education should be a place where freedom is practiced. Educational sites are places for both personal and collective transformation. The author proposes some classroom practices that are an embodiment of the practice of freedom like questioning, awareness-raising, and confrontations. Similarly, Greene in "Education as the Practice of Freedom" (2005) offers the idea that to achieve freedom, teachers should engage cooperatively with their students so that these last develop critical thinking and responsible choice-making. Other authors have contributed to the theory (Shor, 1999); (Giroux, 2016). McLaren (2015) called for questioning of the existing social relations. Darder (2017) offered her ideas on democratic citizenship based on educators being a model critically dedicated to freedom and justice. Deliberations made by Kellner (2003) offered a compression of the existing Deweyan and Freirean theories as well as theories based on race, gender to achieve new literateness against challenges of globalization and diversity of cultures. Even though, another group of researchers warns on what might be the real 
consequences of schools. In reality, students in schools encounter some constraints instead of enjoying freedom, which is more testimony to hierarchy than to equality as in the case of America (Merelman, 1980). This happens due to deficiencies that exist in the education culture.

Stevenson (2010) considers that democratic education is based upon experience. It cannot be limited solely to knowledge transfer. His perspective of democratic education takes into account relations of freedom and authority. Most importantly, he is a supporter of Freire`s critical evaluation of education. Similarly, Hantzopoulos (2015) evaluates critical democratic education based on students' experiences and claims that education does not offer transformation, but it is a place of negotiation and is in continuous change. Howard \& Turner-Nash (2011) reflect on how educational practices are related to democracy.

\subsection{The Deliberative View}

From the deliberative standpoint, the main arguments come from Amy Gutmann. Gutmann (1999), well known for her most important contribution to political theory "Deliberative Democracy", offers a democratic theory of education in her book "Democratic Education". This theory promotes the empowerment of citizens and attachment to democratic values. Debate and communication are part of democratic virtues (Fishkin \& Luskin, 1999). Democratic education targets comprehension and approval of freedom and fairness considering varieties of standpoints. She also suggests egalitarian cosmopolitanism, which is equal respect for citizens and their unique identities. Education is needed to "further democratic politics" (Gutmann, 1999, p. 18).

Supporters of deliberative education suggested normative ideals be reached in education. Parker (2010) defends discussion and deliberation as a practice in education. He is in favor of discussion, debate, and political deliberation over controversial and problematic issues. Hanson \& Howe (2011) argue over educational practices that offer the exchange of arguments and critical outlook of issues to meet ideals of deliberative democracy. Nevertheless, some criticism has been offered as well. Fraser-Burgess (2009) discusses deliberative-focused education over pluralism and how Gutmann's view is a weak version of pluralism since it is based on personal freedom. The scholar offers an educational theory based on reciprocity and at the same time, it is freedom-allowing. Haav (2008) examined the Estonian case to find that no educational authority is focused on deliberative education. And, apart from other defenders of deliberative education in theory (Lefrançois \& Ethier, 2010); political literacy (Hess, 2008), and metadeliberation (Nishiyama, 2021); others pointed to a change of educational practices from the transmission of ideology towards deliberation, research, and compromise (Fallace, 2016).

\section{CONCLUSION}

To summarize, the above-presented review offers a map of considerations over education and politics, generally. The authors included in this review date from different historical periods, without excluding the thoughts of the founders of Greek philosophy. In theory, many have assumed that education is an important element for politics and democracy. The same line of thought has persisted even to nowadays modern authors. The education effect theory and models on education and democratic values have attempted to explain the process. In this inspection of literature, a focus has been given to the impact of education on the democratic value of freedom as conceptualized under the progressivist-liberal, critical and deliberative perspective. Each of these views brings specific insight into the way education impacts the young generation of a country. The points addressed by each author are to be read with caution and further investigation is to be implemented.

\section{REFERENCE LIST}

Adler, M. (1982). The Paideia Proposal: Rediscovering the Essence of Education. Retrieved 12 12, 2021 , from https://www.yumpu.com/en/document/read/17409527/the-paideia-proposalpdf-college-ofeducation

Adler, M. j. (1983). Paideia Problems and Possibilities. NY, London: Macmillan Publishing Company, Collier Macmillan Publishers.

Alemán, E., \& Kim, Y. (2015). The Democratizing Effect of Education. Research and Politics, 1-7.

Alexander, H. (2007). What is Common About Common Schooling? Rational Autonomy and Moral Agency in Liberal Democratic Education. Journal of Philosophy of Education, 41(4), 609-624. 
Proceedings of INTCESS 2022- 9th International Conference on Education \& Education of Social Sciences 17-18 January 2022- Online Conference

Apergis, N. (2017). Education and Democracy: New Evidence from 161 Countries. Economic Modelling, 71. Barro, R. J. (1999). Determinants of Democracy. Journal of Political Economy, 107(S6), S158-S183.

Baum, M. A., \& Lake, D. A. (2003). The Political Economy of Growth: Democracy and Human Capital. American Journal of Political Science, 47(2), 333-347.

Biesta, G. (2007). Education and the Democratic Person: Towards a Political Conception of Democratic Education. Teachers College Record, 109(3), 740-769.

Bittencourt, M. (2014). Democracy and Education: Evidence from the Southern African Development Community. Retrieved from Economic Research South Africa: https://econrsa.org/system/files/publications/working_papers/working_paper_433.pdf

Blake, N., \& Masschelein, J. (2003). Critical Theory and Critical Pedagogy. In N. Blake, P. Smeyers, R. Smith, \& P. e. Standish, The Blackwell Guide to the Philosophy of Education (pp. 38-56). Blackwell Publishing Ltd.

Bowles, S., \& Gintis, H. (2002). Schooling in Capitalist America Revisited. Sociology of Education, 75(1), 118.

Brooke, C., \& Frazer, E. (2010). Political and Philosophical Perspectives on Education. Oxford Review of Education, 36(5), 521-525.

Buchmann, C., \& Hannum, E. (2001). Education and Stratification in Developing Countries: A Review of Theories and Research. Annual Review of Sociology, 27, 77-102.

Carr, P. R., \& Lund, D. E. (2011). Framing Democracy in Education. Counterpoints-Does Your Vote Count? Critical Pedagogy and Democracy, 378, 69-88.

Chen, J. (2008). Democratization and Government Education Provision in East Asia. Journal of East Asian Studies, 8(2), 175-209.

Darder, A. (2017). Reinventing Paulo Freire: A Pedagogy Of Love. New York: Routledge.

Dewey, J. (1916). Democracy and Education. New York: Macmillan.

Duarte, M. (2016). Educating Citizens for Humanism: Nussbaum and the Education Crisis. Studies in Philosophy and Education, 35(5), 463-476.

Durakoglu, A., Bicer, B., \& Zabun, B. (2013). Paulo Freire's Alternative Education Model. The Anthropologist, 16(3), 523-530.

Emler, N., \& Frazer, E. (1999). Politics: The Education Effect. Oxford Review of Education, 25(1/2), 251-273.

Fallace, T. D. (2016). The Origins of Classroom Deliberation: Democratic Education in the Shadow of Totalitarianism, 1938-1960. Harvard Educational Review, 86(4), 506-526.

Fishkin, J. S., \& Luskin, R. C. (1999). The Quest for Deliberative Democracy. The Good Society, 9(1), 4-9.

Forster, G. (2005). John Locke's Politics of Moral Consensus. New York: Cambridge University Press.

Fortunato, P., \& Panizza, U. (2015). Democracy, Education and the Quality of Government. Journal of Economic Growth, 20(4), 333-363.

Fraser-Burgess, S. (2009). Problems with a Weakly Pluralist Approach to Democratic Education. The Pluralist, 4(2), 1-16.

Freire, P. (1970). Pedagogy of the Oppressed. New York and London: The Continuum International Publishing Group Inc.

Fromm, E. (2001). The Fear of Freedom. Oxfordshire: Routledge.

Fukuyama, F. (1992). In the Land of Education. In F. Fukuyama, The End of History and the Man (pp. 109125). New York: Macmillan.

Giroux, H. A. (2016). When Schools Become Dead Zones of the Imagination: A Critical Pedagogy Manifesto. The High School Journal, 99(4), 351-359.

Glaeser, E. L., La Porta, R., Lopez-De-Silanes, F., \& Shleifer, A. (2004). Do Institutions Cause Growth? Journal of Economic Growth, 9(3), 271-303. 
Proceedings of INTCESS 2022- 9th International Conference on Education \& Education of Social Sciences 17-18 January 2022- Online Conference

Glass, R. D. (2004). Moral and Political Clarity and Education as a Practice of Freedom. CounterpointsDemocratic Dialogue in Education: Troubling Speech, Disturbing Silence, 240, 15-32.

Greene, C. (2005). Education as the Practice of Freedom. Educational Horizons, 84(1), 50-53.

Gutmann, A. (1999). Democratic Education. Princeton, New Jersey: Princeton University Press.

Haav, K. (2008). Civic Education in Estonia: Democratic or Authoritarian? Journal of Social Science Education, 9(1), 121-130.

Hanson, J. S., \& Howe, K. R. (2011). The Potential for Deliberative Democratic Civic Education. Democracy \& Education, 19(2), 1-9.

Hantzopoulos, M. (2015). Sites of Liberation or Sites of Despair?: The Challenges and Possibilities of Democratic Education in an Urban Public School in New York City. Anthropology and Education, 46(4), 345-362.

Harber, C. (1997). School Effectiveness and Education for Democracy and Non-violence. Retrieved from UNESDOC-Digital Library: https://unesdoc.unesco.org/ark:/48223/pf0000111227

Held, D. (2006). Models of Democracy. Cambridge: Polity Press.

Hess, D. (2008). Democratic Education to Reduce the Divide. Social Studies Disciplines, 72(7), 373-376.

Howard, K. J., \& Turner-Nash, K. (2011). Alimentar: Theorizing Pedagogy, Curriculum, and Mentorship for Democratic Doctoral Education. Equity \& Excellence in Education, 44(1), 22-39.

Jacoby, W. G. (1988). The sources of liberal-conservative thinking: Education and conceptualization. Political Behavior, 316-332. Retrieved from https://doi.org/10.1007/BF00990806

Karış, Ç., \& Tandoğan, D. (2019). The Effect of Education on Democracy: Panel Data Analysis of High Income Countries. Universal Journal of Educational Research, 7(11), 2425-2431.

Keat, R. (1980). The Critical Theory of Jürgen Habermas. Analytic Philosophy, 21(4), 216-221.

Keating, A., Benton, T., \& Kerr, D. (2012). Evaluating the Impact of Citizenship Education in Schools. In M. Print, \& D. Lange, Schools, Curriculum and Civic Education for Building Democratic Citizens (pp. 5772). Rotterdam: Sense Publishers.

Kellner, D. (2003). Toward a Critical Theory of Education. Democracy \& Nature, 9(1), 51-64.

Kołczyńska, M. J. (2020). Democratic Values, Education, and Political Trust. International Journal of Comparative Sociology, 61(2), 1-58.

Lefrançois, D., \& Ethier, M.-A. (2010). Translating the Ideal of Deliberative Democracy into Democratic Education: Pure Utopia? Educational Philosophy and Theory, 42(3), 271-292.

Lipset, S. M. (1959). Some Social Requisites of Democracy: Economic Development and Political Legitimacy. The American Political Science Review, 53(1), 69-105.

Locke, J. (1692, 2021, January 20). Modern History Sourcebook: John Locke (1632-1704): Some Thoughts Concerning Education, 1692. Retrieved from Fordham University: https://sourcebooks.fordham.edu/mod/1692locke-education.asp

Lodge, R. C. (2000). Plato's Theory of Education. Routledge.

Martin-Sanchez, M., \& Flores-Rodriguez, C. (2018). Freedom and Obedience in Western Education. Journal of Pedagogy, 9(2), 55 - 78.

McLaren, P. (2015). Life in Schools. An Introduction to Critical Pedagogy in the Foundations of Education. New York, NY: Routledge.

Merelman, R. M. (1980). Democratic Politics and the Culture of American Education. The American Political Science Review, 74(2), 319-332.

Meyer, A. (2016, June 5). The Impact of Education on Political Ideology: Evidence from European Compulsory Education Reforms. Retrieved from SSRN: https://papers.ssrn.com/sol3/papers.cfm?abstract_id=2832904

Meyer, J. W. (1977). The Effects of Education as an Institution. American Journal of Sociology, 83(1), 55-77. 
Mill, J. (1859). On Liberty. London : John Parker and Son, West Strand.

Moore, T. (2010). Philosophy of Education. New York: Routledge.

Murphy, M. (2015, April 25). Plato's Philosophy of Education and the Common Core Debate.

Murtin, F., \& Wacziarg, R. (2014). The Democratic Transition. Journal of Economic Growth, 19(2), 141-181.

Naussbam, \& C., M. (2010). Not for Profit-Why Democracy needs the Humanities. Princeton and Oxford: Princeton University Press.

Nishiyama, K. (2021). Democratic Education in the Fourth Generation of Deliberative Democracy. Theory and Research in Education, 19(2), 109-126.

Pangle, T. L. (1985). Socrates on the Problem of Political Science Education. Political Theory, 13(1), 112137.

Parker, W. (2010). Listening to Strangers: Classroom Discussion in Democratic Education. Teachers College Record, 112(11), 2815-2832.

Peca, K. (2000). Critical Theory in Education: Philosophical, Research, Sociobehavioral, and Organizational Assumptions. Retrieved from https://files.eric.ed.gov/fulltext/ED450057.pdf

Pennington, M. (2014). Against Democratic Education. Social Philosophy and Policy, 31(1), 1 - 35.

Print, M. ( 2007). Citizenship Education and Youth Participation in Democracy. British Journal of Educational Studies, 55( 3), 325-345.

Radu, L. (2011). John Dewey and Progressivism in American Education. Bulletin of the Transilvania University of Braşov, Series VII: Social Sciences and Law(2), 85-90.

Rousseau, J.-J. (1762). Emile . Geneva.

Shor, I. (1999). What is Critical Literacy? Journal of Pedagogy, Pluralism, and Practice, 1(4), 2-32.

Sorina, G., \& Griftsova, I. (2017, August 5). Kant's philosophy of education: A dialogue through centuries. Espacios, 38, pp. 42-52.

Stevenson, N. (2010). Critical Pedagogy, Democracy, and Capitalism: Education without Enemies or Borders. Review of Education, Pedagogy \& Cultural Studies, 66-92 .

Stubager, R. (2008). Education Efefcts on Authoritarian-Libertarian Values: A Question of Socialization. The British Journal of Sociology, 59(2), 321-350.

Ten, C. L. (1969). Mill and Liberty. Journal of the History of Ideas, 30(1), 47-68.

Terry, P. R. (1997). Habermas and Education: Knowledge, Communication, Discourse. Curriculum Studies, 5(3), 269-279. Retrieved from https://doi.org/10.1080/14681369700200019

Türedi, S., \& Terzi, H. (2017). The Relationship between Education and Democracy in Turkey. In R. Yilmaz, \& G. Löschnigg, Studies on Balkan and Near Eastern Social Sciences (pp. 209-221). Frankfurt and Main: Peter Lang GmbH.

Wain, K. (2004). Habermas: The Rational Society. Counterpoints, 260, 135-181.

West, E. G. (1965). Liberty and Education: John Stuart Mill's Dilemma. Philosophy, 40(152), 129-142. 